\title{
Anatomical characterization of vegetative organs and scapes of Rondonanthus (Eriocaulaceae, Poales)
}

\author{
Fernanda Martins Gonzaga de Oliveira ${ }^{1} \cdot$ Aline Oriani $^{1}$
}

Received: 19 December 2015/ Accepted: 8 June 2016/Published online: 27 June 2016

(C) Botanical Society of Sao Paulo 2016

\begin{abstract}
Eriocaulaceae is a pantropical family and comprises ten genera. Rondonanthus is endemic to the north region of South America and comprises six species. The anatomy of roots, stem, leaves, and scapes were studied in four species to characterize the genus and to identify characteristics with taxonomic value. The following characteristics are diagnostic of Rondonanthus: roots-heterogeneous cortex with an aerenchyma supported by arm cells and vascular cylinder with a central metaxylem vessel element; stems-idioblasts with druses in the cortex and in the pith; leaves-Malpighian hairs, hypodermis in the adaxial surface, chlorenchyma with arm cells, druse idioblasts in the mesophyll, and vascular bundle sheath extensions with rounded cells; scapes-Malpighian hairs and chlorenchyma with arm cells. Rondonanthus capillaceus differed from the remaining studied species by presenting roots with a homogeneous cortex with thinwalled cells; filiform leaves without stomata and trichomes but with a chlorophyllous epidermis and a parenchymatous mesophyll and only one central vascular bundle without sheath extension. Such differences may be related to the habitat, since this species grows on river margins and requires hydrodynamic organs. The number of vascular bundles in the leaves is a useful characteristic to differentiate among species.
\end{abstract}

Keywords Anatomy · Leaf - Reproductive axis · Root . Stem

Fernanda Martins Gonzaga de Oliveira

fernanda.martins@hotmail.com

1 UNESP - Departamento de Botânica, Instituto de Biociências, Universidade Estadual Paulista, C Postal 199, Av. 24A, 1515 - Bela Vista, Rio Claro, SP 13506-900, Brazil

\section{Introduction}

Eriocaulaceae comprises about 1400 species grouped into 10 genera and two subfamilies (Giulietti et al. 2012). Paepalanthoideae comprises Rondonanthus, Paepalanthus, Syngonanthus, Comanthera, Leiothrix, Lachnocaulon, Tonina, and Actinocephalus, and is characterized by presenting isostemonous staminate flowers and nectariferous style branches in the pistillate flowers (Ruhland 1903; Herzog 1931; Sano 2004; Parra et al. 2010; Andrade et al. 2011; Giulietti et al. 2012). Eriocauloideae comprises Eriocaulon and Mesanthemum, and its representatives have diplostemonous staminate flowers and petals with glands in both staminate and pistillate flowers (Ruhland 1903; Giulietti et al. 2012). The monophyletism of both subfamilies has already been confirmed, but the intergeneric relationships remain unclear (Andrade et al. 2010; Giulietti et al. 2012).

The species of Eriocaulaceae can be distinguished from other monocotyledons by the presence of a short stem with leaves in rosette, capituliform inflorescences sustained by a long axis (scapes), and by having unisexual flowers with a bi or trilocular ovary with a single pendulous, orthotropous ovule per locule, and spiroaperturate pollen grains (Giulietti et al. 2000). Rondonanthus has as diagnostic characteristic long and linear staminodes in the pistillate flowers, while in the remaining genera, the staminodes are scalelike and microscopic (Hensold and Giulietti 1991).

Rondonanthus comprises six species occurring exclusively in South America, mainly in Guiana Highlands, growing in extremely humid places with high altitude and rocky soils (Hensold and Giulietti 1991). The phylogenetic position of the genus is not clear (Andrade et al. 2010; Giulietti et al. 2012) and its representatives have morphological features intermediate between those of Paepalanthoideae and Eriocauloideae, 
sharing characteristics with both subfamilies (Hensold and Giulietti 1991; Stützel 1998). According to Hensold and Giulietti (1991), the morphological characteristics of Rondonanthus indicate that this genus has derived from Syngonanthus. Therefore its anatomical characterization will contribute to elucidate the infrafamilial relationships and to understand the evolution of vegetative and reproductive characters in the family.

There are several anatomical studies on vegetative organs and scapes of Eriocaulaceae involving mainly species of Paepalanthus, Syngonanthus, Comanthera, Leiothrix, Actinocephalus and Eriocaulon (e.g., Poulsen 1888; Ruhland 1903; Malmanche 1919; Tomlinson 1969; Monteiro et al. 1984, 1985; Castro and Menezes 1995; Scatena and Menezes 1995, 1996a, b; Scatena and Moraes 1996; Scatena et al. 1999a, b, 2004, 2005a, b; Scatena and Rosa 2001; Coan et al. 2002; Oriani et al. 2005, 2008; Alves et al. 2013). According to these studies, there are two types of roots in the family: pale, spongy roots, with a heterogeneous cortex presenting aerenchyma, and brownish roots, with a homogeneous cortex constituted by parenchyma. The stems of Eriocaulaceae may be rhizomatous or aerial, with no thickening or slightly thickened by the primary thickening meristem; or aerial, widely thickened by the secondary thickening meristem. The leaves are bifacial, with stomata restricted to the abaxial surface, collateral vascular bundles arranged in a single row and with sheath extensions. The scapes usually present ribs, which are constituted by chlorenchyma alternated with parenchyma or supporting tissue.

For Rondonanthus, there is available information about the anatomy of the root of $R$. roraimae (Oliv.) Herzog, which has a heterogeneous cortex with aerenchyma (Stützel 1988). Besides this information, little is known about the anatomy of vegetative organs in this genus (Ruhland 1903; Tomlinson 1969) and it is believed that this lack of information is due to the difficulty to access the area where the species grow.

The objective of this work was to analyze anatomically the roots, stems, leaves, and scapes of species of Rondonanthus to characterize the genus in a comparative approach. The anatomical characteristics were also related to the environment.

\section{Materials and methods}

The following species were studied: $R$. acopanensis (Mold.) Hensold \& Giulietti (SPF 160826), R. capillaceus (Klotzsch ex Körn.) Hensold \& Giul. (SPF 111269), $R$. duidae (Gleason) Hensold \& Giul. (SPF 111240) and $R$. roraimae (Scatena et al. 473, 479). The specimens of $R$. roraimae were collected in the Parque Nacional do Monte
Figs. 1-6 Cross sections of the roots of Rondonanthus (Eriocaulaceae). 1, 2 General aspect (1) and detail showing epidermis, heterogeneous cortex, and vascular cylinder (2) of the root of $R$. acopanensis; $\mathbf{3}$ general aspect of the root of $R$. capillaceus; $\mathbf{4}$ detail of the root of $R$. duidae showing inner cortex, endodermis, and pericycle; 5, 6 general aspect (5) and detail showing epidermis, heterogeneous cortex, and vascular cylinder (6) of the root of $R$. roraimae. Scale bars $=100 \mu \mathrm{m}(\mathbf{1}, \mathbf{5}), 50 \mu \mathrm{m}(\mathbf{2}, \mathbf{3}, \mathbf{6}), 30 \mu \mathrm{m}(\mathbf{4})$. $E$ epidermis, $E n$ endodermis, $I C$ inner cortex, $M C$ median cortex, $O C$ outer cortex, $P$ pericycle, Arrows arm cells

Roraima (Roraima State, Brazil). Vouchers were deposited in the Herbarium Rioclarense of the Instituto de Biociências at Universidade Estadual Paulista (HRCB). Samples of the remaining species were obtained from herbarium specimen vouchers from the Herbário da Universidade de São Paulo (SPF).

For the anatomical study, the collected material was fixed in FAA 50 (50\% ethanol, $37 \%$ formaldehyde, glacial acetic acid; $18: 1: 1 \mathrm{v} / \mathrm{v})$ and stored in $70 \%$ ethanol (Johansen 1940). The herborized material was boiled in distilled water with drops of glycerin and detergent for expansion of the tissues and stored in $70 \%$ ethanol (Johansen 1940). Cross sections were handmade with razor blades in the median region of mature roots, stems, leaves, and scapes (inflorescence axis) from, at least, three individuals of each species. Only for $R$. acopanensis it was not possible to obtain samples of the stem. Paradermal sections were also prepared from the median region of the leaves and scapes. The sections were stained with basic fuchsin and astra blue (Roeser 1972) and mounted on semipermanent slides with glycerin jelly. The results were documented with images obtained with an image-capturing device (Leica DFC295) coupled to a microscope (Leica DMLB), using the software LAS (Leica Application Suite 4.0 Version).

\section{Results}

\section{Root}

In all the studied species, the roots have a single-layered epidermis with thin-walled cells (Figs. 1, 2, 5, 6) and root hairs (Fig. 5). In the roots of $R$ acopanensis, $R$. duidae, and $R$. roraimae, the cortex is heterogeneous (Figs. 1, 2, 5, 6): the outer cortex (exoderm) is constituted by one layer of thin-walled cells; the median cortex is constituted by aerenchyma, with cells whose periclinal walls rupture, and their remaining anticlinal walls delimit air spaces; and the inner cortex presents three to five cell layers, the inner ones with U-shaped thick-walled cells (Figs. 1, 2, 4, 6). In the median cortex, there are also arm cells supporting the 

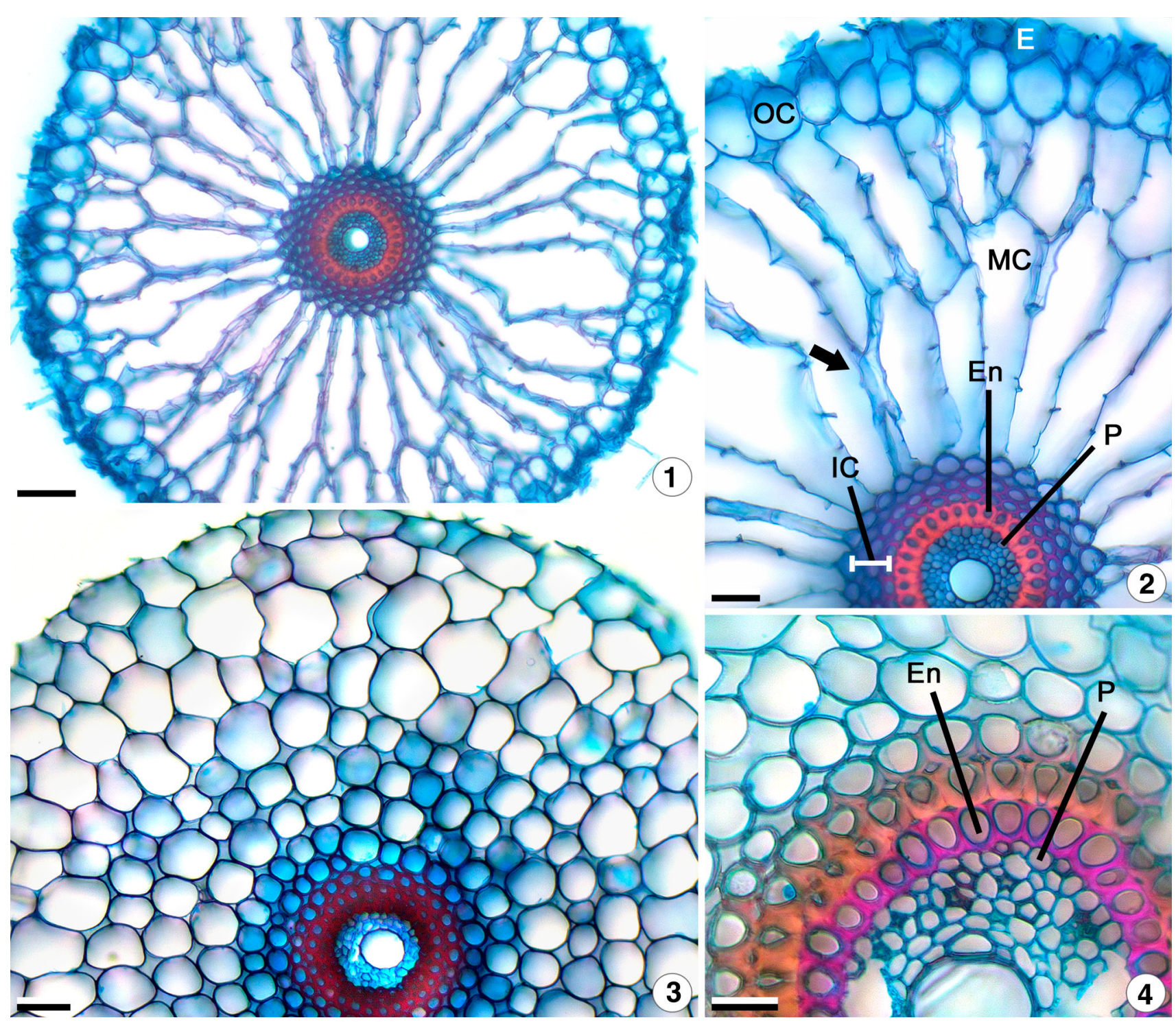

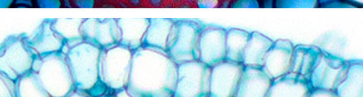
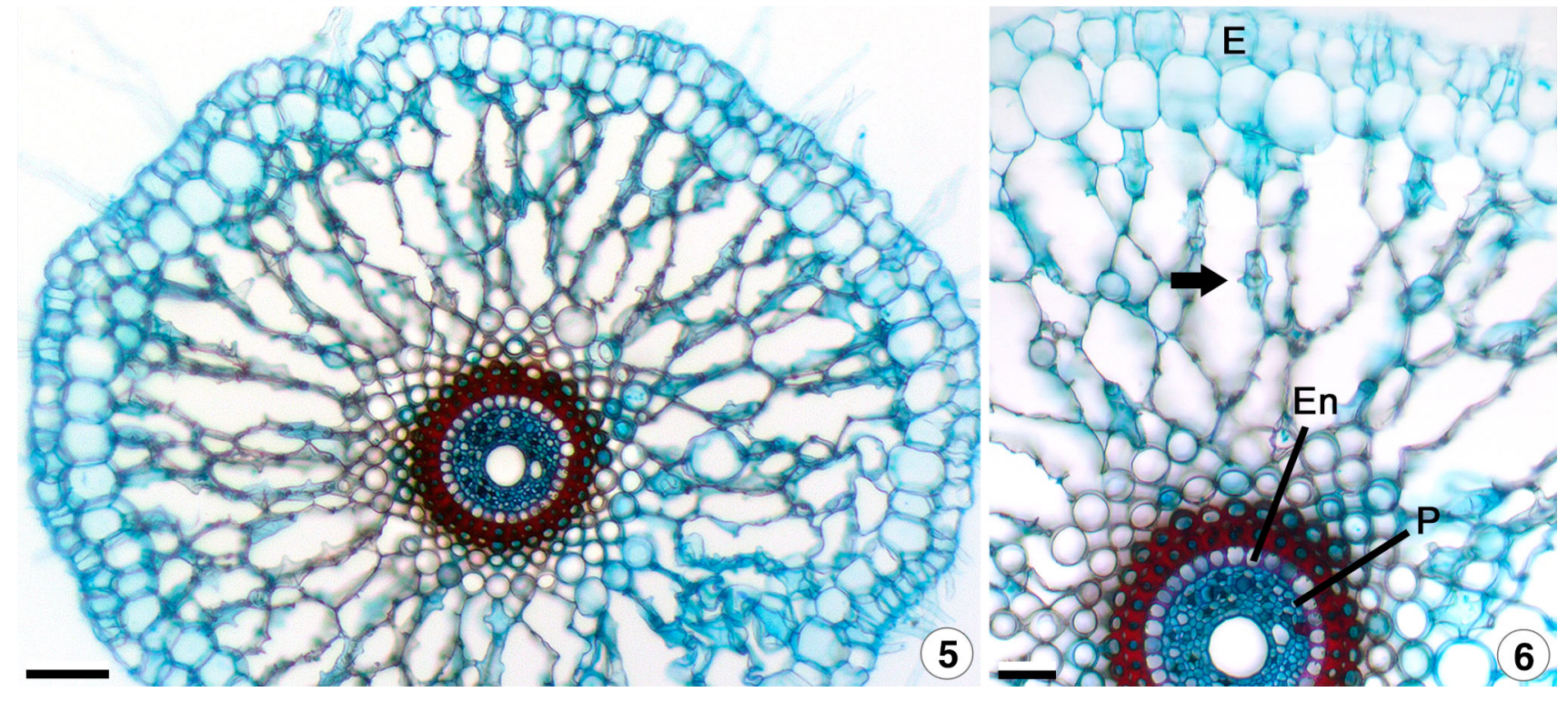
aerenchyma (Figs. 2, 6-arrows). In $R$. capillaceus, the cortex is homogeneous, constituted by thin-walled cells and by two or three inner layers of cells with thickened walls (Fig. 3). In all the studied species, the endodermis is single-layered and composed of thick-walled cells (Figs. 2, $4,6)$. In the vascular cylinder, the pericycle is single-layered and constituted by thin-walled cells (Figs. 2, 4, 6), and there is one bigger metaxylem vessel element occupying the central position (Figs. 1-6). In $R$. duidae and $R$. roraimae, besides the central metaxylem vessel element, there are other two or three smaller ones (Figs. 5, 6).

\section{Stem}

The stems of $R$. capillaceus, $R$. duidae and $R$. roraimae have an epidermis with thin-walled cells and multicellular, unisseriate trichomes (Fig. 10-arrow). The cortex is composed of isodiametric parenchymatous cells (Figs. 7, 8, 1012) and has leaf traces (Figs. 10,12) and adventitious roots (Figs. 7, 11). The vascular cylinder is delimited by a single-layered pericycle with thick-walled cells (Figs. 8, 10, 12). The vascular bundles are amphivasal (Fig. 10), randomly distributed, and the pith is parenchymatous (Figs. 7, $8,10)$. In more robust individuals, the stem is slightly thickened, with a wider vascular cylinder (Fig. 7). Idioblasts with druses (Fig. 9) are present in both the cortex and the pith of all the studied species (Fig. 7, 11, 12-arrow heads).

\section{Leaf}

The leaves are linear and hipostomatic (Figs. 13, 18, 19, 21 ), except for $R$. capillaceus leaves that are filiform and do not present stomata (Fig. 17). The stomata are paracytic (Fig. 22), do not present specialized substomatal chamber, and are located slightly above the other epidermal cells (Fig. 23). In frontal view, the epidermal cells are elongate (Fig. 22), except for $R$. capillaceus that has short, clorophyllous epidermal cells (Figs. 16, 17). In cross section, the epidermis is single-layered and has cells with completely thickened walls and reduced lumen in $R$. acopanensis (Figs. 13, 14), thin walls in $R$. capillaceus (Fig. 17), and thickened outer periclinal walls in $R$. duidae (Figs. 18, 19) and $R$. roraimae (Fig. 21). T-shaped trichomes (Malpighian hairs) are present on both surfaces of the leaf blade of $R$. acopanensis, $R$. duidae and $R$. roraimae (Figs. 13, 14, 18 -arrow heads).

The mesophyll presents an adaxial hypodermis that is single-layered and constituted by thick-walled cells in $R$. acopanensis (Fig. 13), and multilayered with thin-walled or slightly thick-walled cells in R. duidae (Figs. 18, 19) and $R$. roraimae (Fig. 21). In $R$. capillaceus, the hypodermis is cylindrical, single-layered, and constituted by thin-walled
Figs. 7-12 Cross sections of the stems of Rondonanthus (Eriocaulaceae). 7, 8 General aspect of the stem of $R$. capillaceus (7) and $R$. duidae $(\mathbf{8}), 9,10$ detail showing the idioblasts with druses $(\mathbf{9})$ and general aspect (10) of the stem of $R$. roraimae; note the presence of leaf traces diverging from the central cylinder, 11 detail showing the cortex and central cylinder of the stem of $R$. duidae; note the formation of an adventitious root; 12 detail of the cortex and central cylinder of the stem of $R$. roraimae showing idioblasts with druses. Scale bars $=70 \mu \mathrm{m}(\mathbf{7}), 100 \mu \mathrm{m}(\mathbf{8 , 1 0 , 1 2}), 15 \mu \mathrm{m}(\mathbf{9}), 50 \mu \mathrm{m}(\mathbf{1 1})$; $A R$ adventitious root, $E$ epidermis, $L T$ leaf trace, $P$ pericycle, Arrow trichomes, Arrow heads druses

cells; the hypodermal cells have a smaller lumen than the remaining mesophyll cells, which are parenchymatous and isodiametric (Fig. 17). In R. acopanensis (Figs. 13, 14), $R$. duidae (Figs. 18, 19), and $R$. roraimae (Fig. 21), the mesophyll has a chlorenchyma composed of arm cells. In $R$. capillaceus and $R$. roraimae, the mesophyll also has idioblasts with druses (Fig. 15). The vascular bundles are collateral (Figs. 13, 14, 17-21) and distributed in a single row (Figs. 13, 19, 21). They are surrounded by a double sheath, the outer one composed of cellulosic thin-walled cells and the inner one composed of lignified thick-walled cells (Figs. 14, 20). Except for $R$. capillaceus (Fig. 17), the vascular bundles have sheath extensions with rounded, lignified, and thick-walled cells in $R$. acopanensis (Figs. 13, 14), and thin-walled or slightly thick-walled cells in $R$. duidae (Figs. 18, 19) and $R$. roraimae (Fig. 21). Such extensions face both leaf surfaces in the central bundle and only the adaxial one in the remaining bundles of $R$. duidae (Figs. 18, 19) and face both surfaces or only one (adaxial or abaxial) in $R$. acopanensis (Fig. 13) and R. roraimae (Fig. 21). The number of vascular bundles is equal to one in $R$. capillaceus (Fig. 17) and varies from three to five in $R$. duidae (Figs. 18, 19), from 6 to 15 in $R$. roraimae (Fig. 21), and from 16 to 25 in R. acopanensis (Fig. 13).

\section{Scape}

In the scapes, the epidermis is composed of completely thick-walled cells in $R$. acopanensis (Figs. 24, 27), slightly thick-walled cells in $R$. capillaceus (Fig. 25), and cells with thickened outer periclinal walls in $R$. duidae (Fig. 26) and $R$. roraimae (Figs. 28, 30). T-shaped trichomes (Malpighian hairs) are present in $R$. acopanensis, $R$. duidae, and $R$. roraimae (Fig. 28). As in the leaves, such trichomes have a distal two-armed cell with asymmetric arms extending parallel to the leaf surface (Fig. 29). The stomata are paracytic and located slightly above the other epidermal cells, without a specialized substomatal chamber (Figs. 24, 27, 30-arrows). In the scapes of $R$. capillaceus, the stomata are absent. There is a single-layered hypodermis that is continuous in $R$. capillaceus (Fig. 25) and discontinuous in 


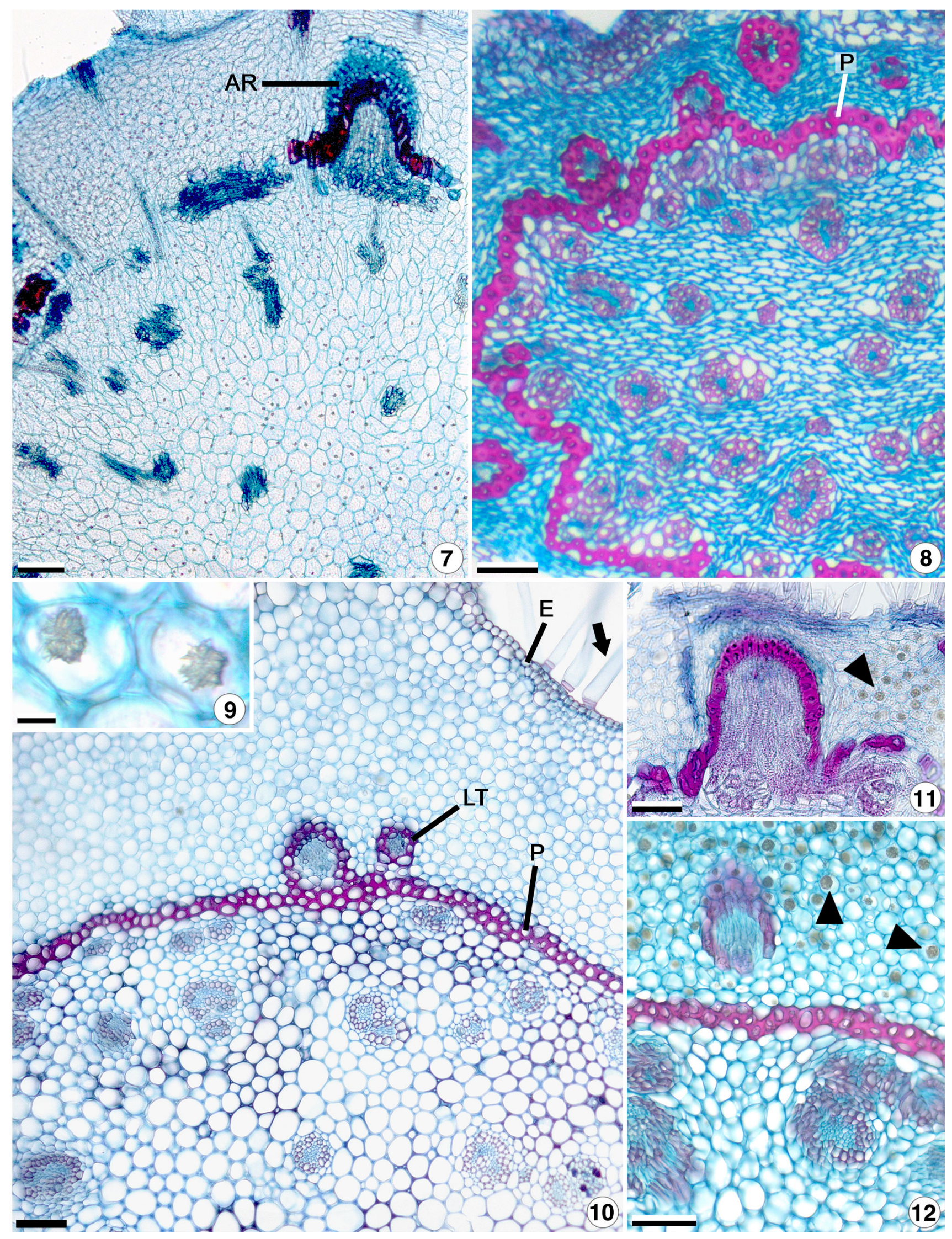


the remaining species (Figs. 27, 30). The cortex is constituted by supporting tissue (sclerenchyma and/or collenchyma) in $R$. acopanensis (Figs. 24, 27), R. duidae (Fig. 26), and $R$. roraimae (Figs. 28, 30), and by parenchyma in $R$. capillaceus (Fig. 25). The supporting tissue or parenchyma alternates with a loose chlorenchyma, forming ribs (Figs. 24-28, 30). The chlorenchyma is composed of arm cells (Fig. 30). The number of ribs is three in $R$. capillaceus (Fig. 25), five in $R$. acopanensis (Fig. 24), six in R. duidae (Fig. 26), and varies from 5-7 in $R$. roraimae (Fig. 28). The endodermis has thin-walled cells and is continuous in R. capillaceus (Fig. 25) and $R$. roraimae (Figs. 28, 30), and discontinuous in $R$. acopanensis (Figs. 24, 27) and $R$. duidae (Fig. 26), involving the smaller vascular bundles. The vascular cylinder is delimited by a continuous pericycle constituted by cells with partially thickened walls. The pericycle is stellate, surrounding completely the smaller bundles and partially the bigger ones (Figs. 27, 30). The vascular bundles are collateral, and the pith is parenchymatous, constituted by thinwalled or partially thick-walled cells (Figs. 24-26, 28). In $R$. acopanensis and $R$. duidae, the vascular bundles are simple and cylindrically distributed forming a ring: the bigger vascular bundles face the supporting tissue and alternate with the smaller ones, which face the chlorenchyma (Figs. 24, 26, 27). In R. capillaceus (Fig. 25), there are two rings of vascular bundles, the outer one is formed by simple and smaller vascular bundles, and the inner one is formed by compound bigger vascular bundles. $R$. roraimae (Fig. 28) also presents two rings of vascular bundles, both formed by simple or compound vascular bundles of similar sizes.

The anatomical characteristics of roots, leaves, and scapes that varied among the studied species are shown in Table 1.

\section{Discussion}

By comparing the results herein obtained to those available in the literature for the other genera of Eriocaulaceae (e.g., Poulsen 1888; Ruhland 1903; Malmanche 1919; Tomlinson 1969; Monteiro et al. 1984, 1985; Stützel 1988; Scatena 1990; Castro and Menezes 1995; Scatena and Rocha 1995; Scatena and Menezes 1995, 1996a, b; Scatena et al. 1999a, b, 2004, 2005a, b; Scatena and Rosa 2001; Coan et al. 2002; Oriani et al. 2005, 2008; Alves et al. 2013), Rondonanthus can be characterized by one central metaxylem vessel element in the vascular cylinder of the roots; druse idioblasts in the cortex and pith of the stems; chlorenchyma with arm cells; and the absence of specialized substomatal chambers in the leaves and scapes. Idioblasts with druses in the mesophyll and two whorls of
Figs. 13-23 Cross $(13-15,17-21,23)$ and paradermal $(\mathbf{1 6}, \mathbf{2 2})$ sections of the leaves of Rondonanthus (Eriocaulaceae). 13, 14 General aspect (13) and detail showing epidermis with stomata and trichomes, chlorenchyma with arm cells, and vascular bundles surrounded by a double sheath (14) in the leaf of $R$. acopanensis; $\mathbf{1 5}$ detail of the druse present in the mesophyll of $R$. roraimae; 16 frontal view of the epidermis of $R$. capillaceus; 17-19 General aspect of the leaves of $R$. capillaceus (e) and $R$. duidae (f, g); 20 detail showing epidermis and vascular bundles of the leaf of $R$. duidae; 21 general aspect of the leaf of $R$. roraimae; 22 Frontal view of the epidermis of $R$. roraimae; $\mathbf{2 3}$ Detail of the stoma of the leaf of $R$. acopanensis. Scale bars: $100 \mu \mathrm{m}(\mathbf{1 3}, \mathbf{1 9}, \mathbf{2 1}), 50 \mu \mathrm{m}(\mathbf{1 4}, \mathbf{1 7}, \mathbf{1 8}, \mathbf{2 0}$, 22), $30 \mu \mathrm{m}(\mathbf{1 4}, \mathbf{1 5}, \mathbf{2 3}) . E$ epidermis, $H$ hypodermis, $I S$ inner sheath, OS outer sheath, Arrows stomata; Arrow heads trichomes

vascular bundles in the scape are exclusive characters of $R$. capillaceus and $R$. roraimae, and are for the first time related here for the family.

We observed in Rondonanthus two anatomical patterns of roots as it occurs in the whole family. However, in Rondonanthus, the roots with heterogeneous cortex are not pale and spongy, and do not differ morphologically from the roots with homogeneous cortex, which are usually brownish and thinner (Tomlinson 1969; Stützel 1988; Scatena et al. 2005a). According to Scatena et al. (2005a), the anatomical pattern of the roots of Eriocaulaceae have not taxonomic value, rather they are influenced by the environment where the species occur. Roots with heterogeneous cortex, with aerenchyma, are present in aquatic species, whereas roots with homogeneous cortex are present in species that grow on mesic or xeric soils. In amphibious species such as Leiothrix fluitans, both types of roots can be present in the same individual probably having two distinct functions: while the roots with heterogeneous cortex are mainly absorptive, the roots with homogeneous cortex fix the plant to the substrate (Coan et al. 2002; Scatena et al. 2005a). The presence of water in the soil causes an accumulation of hydrocarbons in the plant, such as ethylene, which stimulates cellulase production (Smith and Russel 1966). The cellulase degrades the cell walls leading to the formation of aerenchyma, as observed in the roots of aquatic and amphibious Eriocaulaceae species.

The individuals of Rondonanthus usually grow in high altitudes, between 1600 and $2800 \mathrm{~m}$, in very humid places (Hensold and Giulietti 1991; Stützel 1998). The soil is rocky, flat, or with depressions, allowing the formation of flooding spots. The presence of aerenchyma in the roots may be interpreted therefore as an adaptive characteristic, facilitating gas exchange. Rondonanthus capillaceus is an exception because it has an aquatic habit but roots with homogeneous cortex. This species, however, grows fixed on rocks in the margin of rivers with rapidly flowing water (Hensold and Giulietti 1991), which requires roots with strong adherence to the rocks.

It is important to highlight that in the roots of Rondonanthus the aerenchyma is sustained by arm cells that 

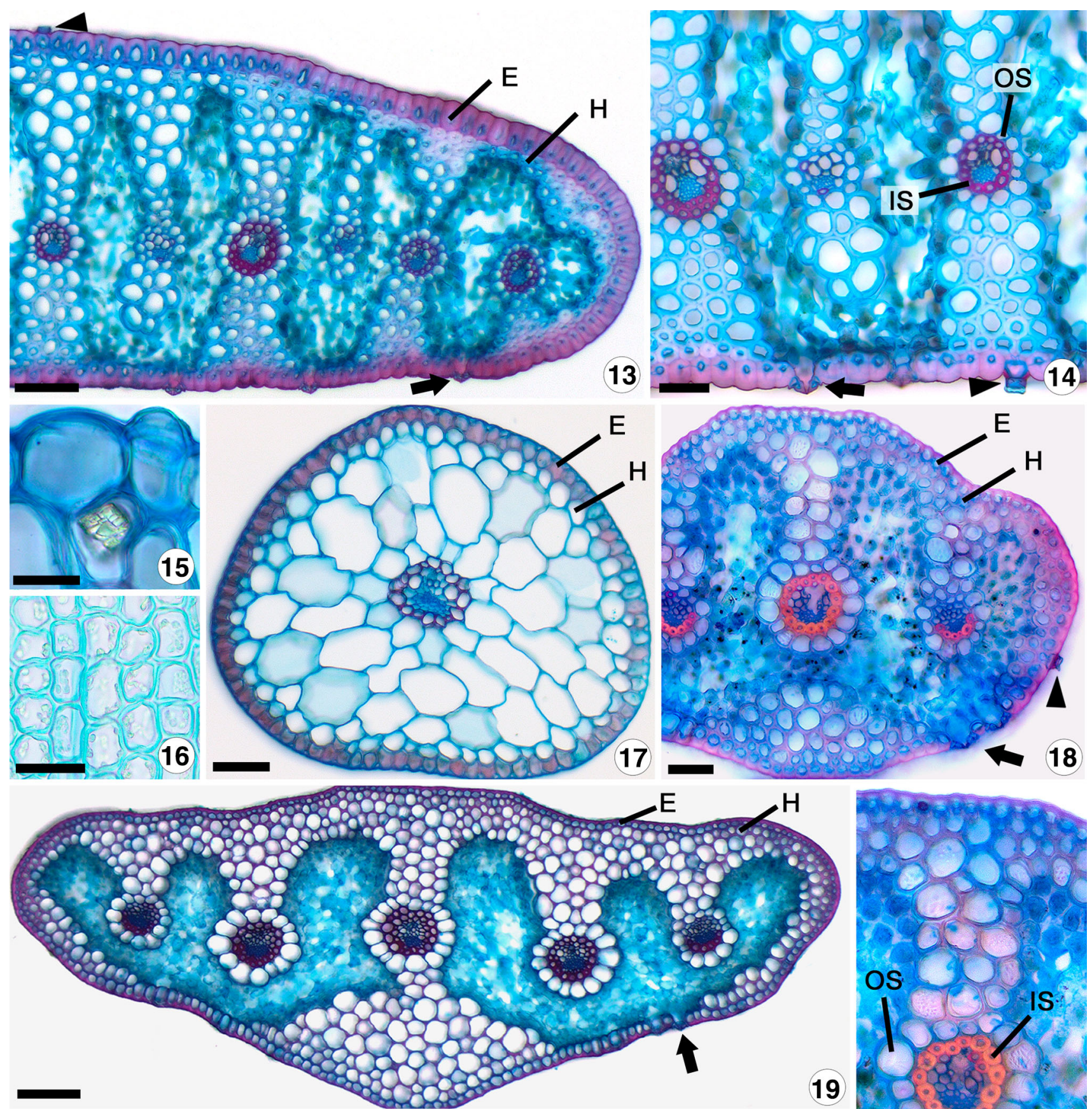

19
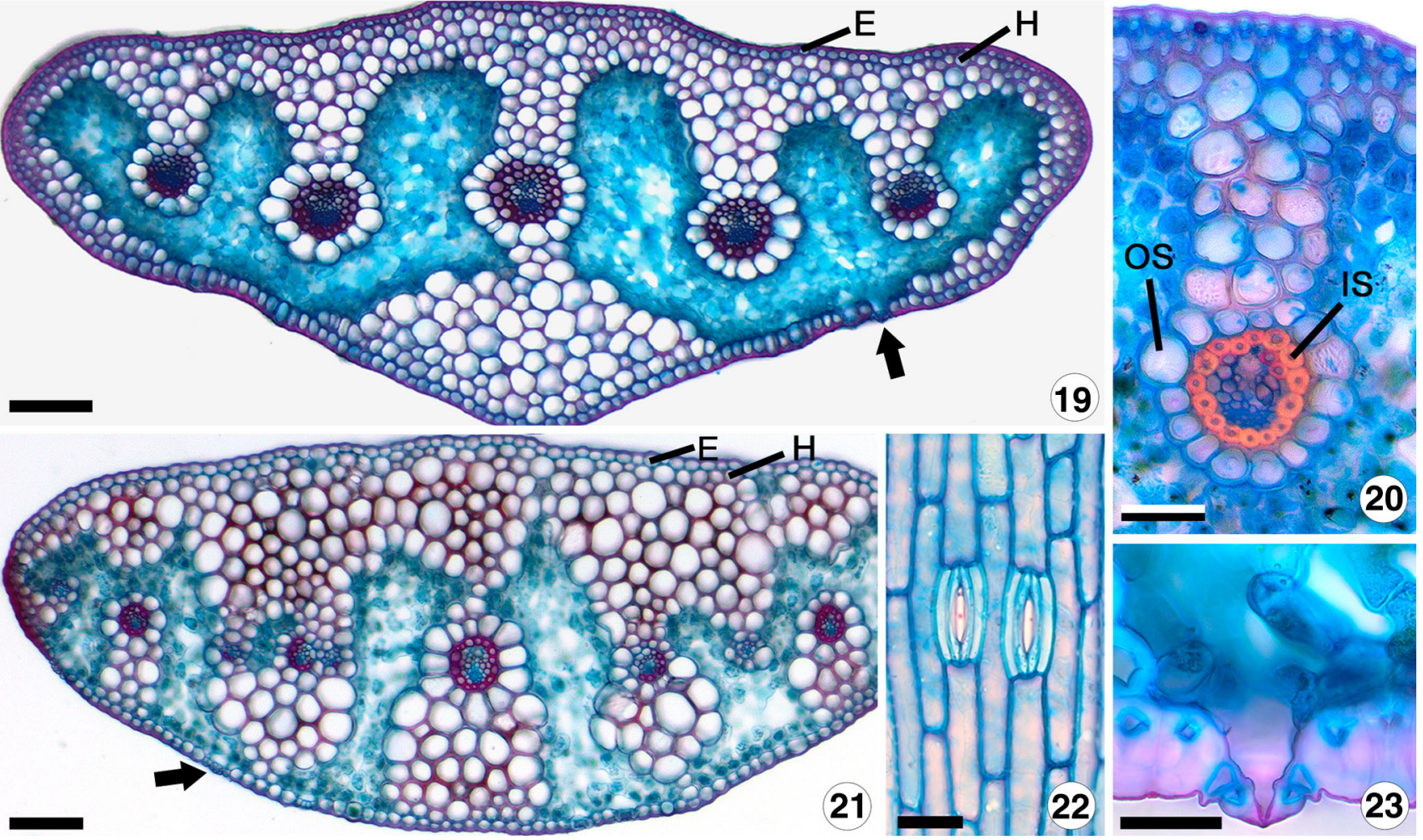
occur in the middle cortex, as it was observed in species of other genera such as Syngonanthus, Comanthera, Paepalanthus and Leiothrix (Stützel 1988; Scatena and Menezes 1996b; Coan et al. 2002). In Eriocaulon and Paepalanthus macropodus, these arm cells are grouped forming diaphragms that transversally cross the air lacunae with the role of maintaining the integrity of the physical space in which the air is stored, facilitating gas exchange (Stuitzel 1988; Scatena and Moraes 1996; Scatena et al. 1999b).

Eriocaulaceae generally presents stems constituted by a single-layered epidermis, a parenchymatous cortex, and a pericycle with thick-walled cells; the stele is of eustele or atactostele type (Tomlinson 1969; Scatena and Menezes 1995; Scatena and Rocha 1995; Scatena et al. 1999a, 2005a; Scatena and Rosa 2001; Coan et al. 2002; Oriani et al. 2008). The primary thickening described for the Eriocaulaceae stems is promoted by divisions of the Primary Thickening Meristem (PTM) (Tomlinson 1969; Scatena and Menezes 1995; Oriani et al. 2008), which corresponds to the pericycle (Menezes et al. 2005). In stems with a primary thickening, the PTM (or pericycle) forms vascular bundles that are scattered through the periphery of the central cylinder (Scatena and Menezes 1995), as observed in other monocot species (Diggle and DeMason 1983). In the stems with a secondary thickening, as it occurs in Actinocephalus species (Oriani et al. 2008), the STM forms parenchyma and amphivasal vascular bundles that have a radial distribution (Diggle and DeMason 1983; Scatena and Menezes 1995). The stems of Rondonanthus generally have an atactostele (stele with many vascular bundles scattered randomly in the central ground tissue) and are not thickened, as observed in the rhizomatous species of Eriocaulaceae (Tomlinson 1969; Scatena and Menezes 1995; Scatena et al. 1999a; Oriani et al. 2008). However, in more robust individuals of Rondonanthus, the stem may be slightly thickened probably as a result of the pericycle activity. In such individuals, the pericycle (or PTM) adds parenchyma and vascular bundles to the central cylinder, as reported for other Eriocaulaceae species with primary thickening (Tomlinson 1969; Scatena and Menezes 1995; Scatena et al. 1999a; Oriani et al. 2008). The different anatomical patterns found for the stems of Eriocaulaceae are related to their morphology (that may be aerial, with long internodes; aerial, with short internodes; or rhizomatous) and due to the high variation of this character, it appears to be not useful for characterizing the genera.

The main anatomical characteristic of the stem that differentiates Rondonanthus from the remaining genera is the presence of druses in the cortex and pith cells. Although Tomlinson (1969) has described that calcium oxalate crystals could be present in not specialized tissues
Figs. 24-30 Cross (24-28, 30) and longitudinal (29) sections of the scapes of Rondonanthus (Eriocaulaceae). 24-26 General aspect of the scape of $R$. acopanensis (24), $R$. capillaceus (25), and $R$. duidae (26); 27 Detail showing epidermis, cortex, and vascular cylinder of the scape of $R$. acopanensis; 28-30 general aspect (28) and details showing Malpighian hair (29), epidermis, cortex, and vascular cylinder (30) of the scape of $R$. roraimae. Scale bars: $100 \mu \mathrm{m}$ (24-26, 28, 30), $50 \mu \mathrm{m}(\mathbf{2 7}, \mathbf{2 9})$; $E n$ endodermis, $H$ hypodermis, $P$ pericycle, Arrows stomata, Arrow heads trichomes

of the vegetative organs of Eriocaulaceae, this characteristic had only been reported for young stems of Syngonanthus and interpreted as a protection against herbivory in the meristematic region (Scatena 1990). In Rondonanthus, the druses are present in the stems of the adult individuals of all the studied species and also in the mesophyll of $R$. capillaceus and $R$. roraimae. Since the genus is restricted to the tepuis of Guiana Highlands, which has peculiar environmental conditions, such crystals may be interpreted as an adaptive characteristic: they may avoid herbivory or may have a physiological function, helping the reduction of excessive calcium in the plant, as demonstrated in other angiosperm species (Keates et al. 2000; Molano-Flores 2001).

It can be emphasized that the leaves and scapes of Rondonanthus are the organs that provide more characteristics with taxonomic value. Among these characteristics, the number of vascular bundles in the leaves is the most important one to differentiate among the species. The characteristics with diagnostic value are given below:

$R$. acopanensis-leaves: epidermis, hypodermis, and vascular bundles sheath extensions constituted by thickwalled cells, single-layered hypodermis, and more than fifteen vascular bundles in the mesophyll; scapes: epidermal cells with completely thickened walls, discontinuous hypodermis and endodermis, with the number of ribs being equal to five, and a single whorl of simple vascular bundles.

$R$. capillaceus-leaves: filiform, cylindrical, with chlorophyllous thin-walled epidermal cells, stomata and trichomes absent, mesophyll with a single-layered hypodermis, a parenchymatous tissue with druse idioblasts, and a single vascular bundle; scapes: cortex constituted by parenchyma alternating with chlorenchyma, continuous hypodermis and endodermis, with the number of ribs being equal to three, and the presence of two whorls of simple and compound vascular bundles. $R$. duidae-leaves: multilayered hypodermis and from three to five vascular bundles; scapes: discontinuous hypodermis and endodermis, with the number of ribs being equal to six, and a single whorl of simple vascular bundles. 

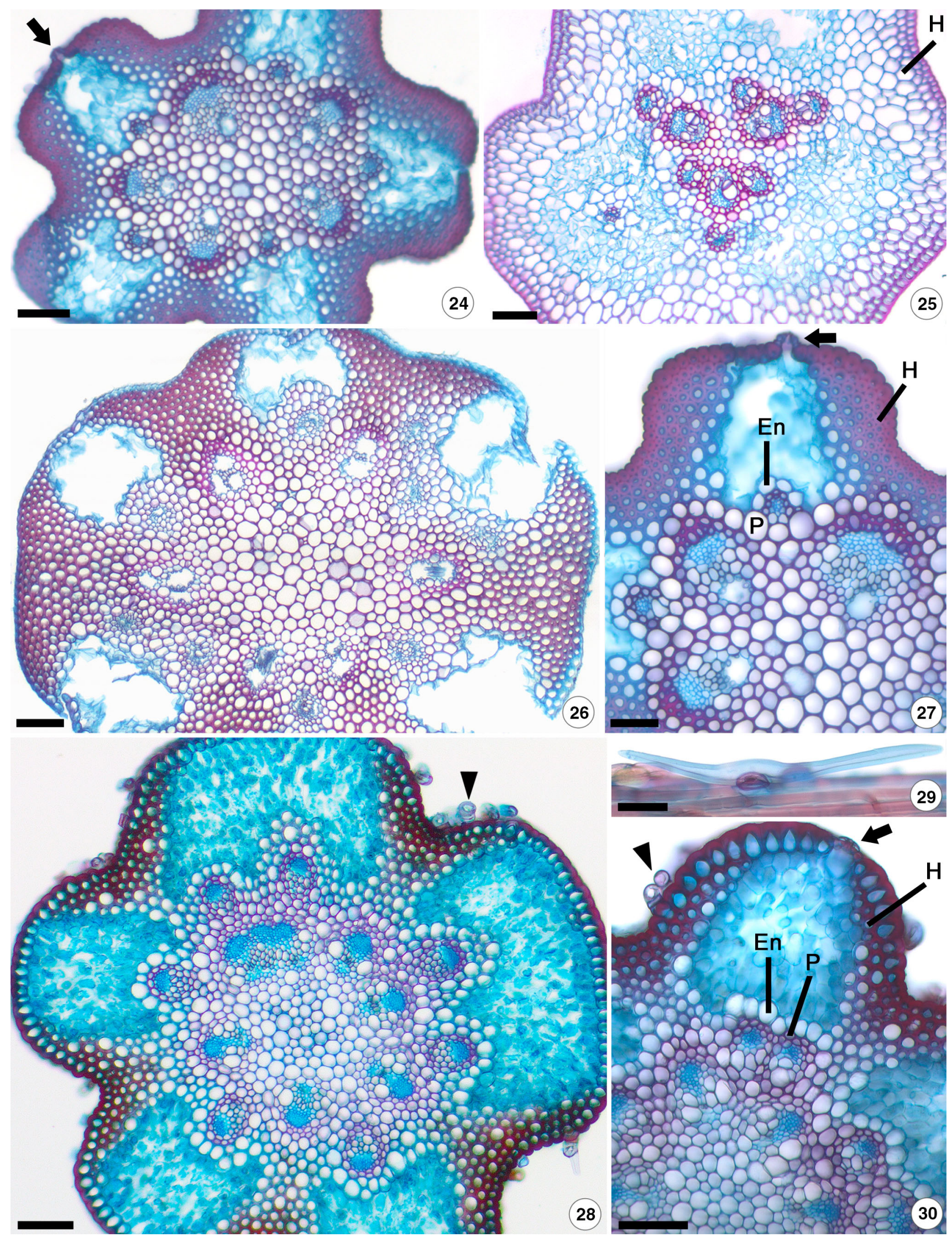
Table 1 Anatomical characteristics of root, leaf and scape of Rondonanthus (Eriocaulaceae)

\begin{tabular}{l} 
Characteristics \\
\hline Root \\
Heterogeneous cortex with aerenchyma \\
Homogeneous cortex \\
One central metaxylem vessel element \\
One central metaxylem vessel element and $2-3$ smaller ones \\
Leaf \\
Elongate epidermal cells \\
Short and chlorophyllous epidermal cells \\
Epidermal cells with completely thickened walls \\
Epidermal cells with thin walls \\
Epidermal cells with thickened outer periclinal walls \\
Stomata restricted to the abaxial surface \\
Stomata absent \\
Trichomes on both surfaces \\
Trichomes absent \\
Hypodermis restricted to adaxial surface \\
Cylindrical hypodermis \\
One-layered hypodermis \\
Multilayered hypodermis
\end{tabular}

1

2

Hypodermis with completely thick-walled cells

Hypodermis with thin-walled or slightly thick-walled cells

Mesophyll with chlorenchyma

Mesophyll with isodiametric parenchymatous cells

Idioblasts with druses in the mesophyll

Vascular bundle sheath extensions facing both leaf surfaces in the central bundle and facing only the adaxial surface in the remaining ones

Vascular bundle sheath extensions facing both surfaces or only one $\quad \mathrm{X}$

Vascular bundle sheath extensions with thick-walled cells

Vascular bundle sheath extensions with thin-walled or slightly thick-walled cells

Number of vascular bundles equal to 1

Number of vascular bundles varying from 3 to 5

Number of vascular bundles varying from 6 to 15

Number of vascular bundles higher than 15

Scape

Epidermal cells with completely thickened walls

Epidermal cells with slightly thickened walls

Epidermal cells with thickened outer periclinal walls

Presence of trichomes

Presence of stomata

Cortex with sclerenchyma or collenchyma alternated with chlorenchyma

Cortex with parenchyma alternated with chlorenchyma

Continuous hypodermis

Discontinuous hypodermis

Continuous endodermis

Discontinuous endodermis

Number of ribs equal to 3

Number of ribs equal to 5

Number of ribs equal to 6

X
$\mathrm{X}$

$X$

$\mathrm{X}$

$\mathrm{X}$

$\mathrm{X}$

$\mathrm{X}$

$\mathrm{X}$

$\mathrm{X}$

$\mathrm{X}$

$\mathrm{X}$

X

$\mathrm{X}$

$\mathrm{X}$ $\mathrm{X}$

$\mathrm{X} \quad \mathrm{X}$

X

X

X

X

X

X

X

X

X

X

X

X

X

X X

X

X

X

X

X

X

X

X

X

X

X

X

X

X

X

X

X

X

X

X

X X

X

X

$\mathrm{X}$

X 
Table 1 continued

\begin{tabular}{lrr}
\hline Characteristics & 1 & 2 \\
\hline One whorl of vascular bundles in the central cylinder & $\mathrm{X}$ & $\mathrm{X}$ \\
Two whorls of vascular bundles in the central cylinder & $\mathrm{X}$ & $\mathrm{X}$ \\
$\begin{array}{l}\text { Simple vascular bundles } \\
\text { Simple and compound vascular bundles }\end{array}$ & $\mathrm{X}$ \\
\hline
\end{tabular}

1 Rondonanthus acopanensis, 2 R. capillaceus, 3 R. duidae, 4 R. roraimae

$R$. roraimae-leaves: multilayered hypodermis, the presence of druse idioblasts in the mesophyll, and the number of vascular bundles varying in the range of 6-15; scapes: discontinuous hypodermis, continuous endodermis, 5-7 ribs, and two whorls of simple and compound vascular bundles.

The presence of a hypodermis and cells with partially or completely thickened walls in the leaves and scapes of most species may be related to the environment, as the species occur in high altitude places with influence of intense luminosity and constant winds. These characteristics may protect the organs from excessive radiation (Terashima et al. 2001) and may provide mechanical support to leaves and scapes, preventing physical damage (Scatena and Scremin-Dias 2012). The presence of trichomes in the leaves and scapes of most Rondonanthus species may also protect these organs from intense radiation. Such trichomes are branched glandular hairs (T-shaped or Malpighian hairs), described by Tomlinson (1969) also in the leaves of Paepalanthus, Syngonanthus, and Leiothrix species and by Monteiro et al. (1979) in the floral bracts of Paepalanthus and Syngonanthus species.

The presence of a hypodermis in the Rondonanthus leaves is a characteristic shared with Paepalanthus, Syngonanthus, Comanthera and a few species of Leiothrix, all of these genera included in Paepalanthoideae (Castro and Menezes 1995; Scatena and Rocha 1995; Scatena and Menezes 1996a; Scatena and Moraes 1996). The presence of vascular bundles sheath extensions constituted by rounded cells in cross section is shared with Syngonanthus, Leiothrix (Paepalanthoideae), and Eriocaulon (Eriocauloideae) (Monteiro et al. 1985; Scatena and Menezes 1996a; Scatena et al. 1999b). The presence of chlorenchyma formed by arm cells in the mesophyll is shared with Paepalanthus (Paepalanthoideae) and Eriocaulon (Eriocauloideae) (Castro and Menezes 1995; Scatena et al. 1999b), indicating that Rondonanthus presents intermediate characteristics between the two subfamilies, as it has already been observed in relation to floral morphology (Hensold and Giulietti 1991).

The species of Rondonanthus present significant similarity with other aquatic species of Eriocaulaceae from different genera, as Syngonanthus caulescens (Poir.) Ruhland, Philodice hoffmannseggii Mart., Tonina fluviatilis Aubl., Paepalanthus obtusifolius (Stand.) Koern., Leiothrix fluitans (Mart.) Ruhland, and Eriocaulon elichrysoides Bong. (Coan et al. 2002). Among the shared characteristics, it can be cited the absence of supporting tissue in the leaves and the absence of specialized substomatal chambers in the leaves and scapes. Therefore, such homoplasious characteristics resulted from adaptive convergence.

It is noteworthy that $R$. capillaceus presented a greater number of distinctive characteristics, which may be related to its habitat. As this species occurs in lower altitudes, between 1000 and $1600 \mathrm{~m}$, adhered to rocks at margins of rivers that overflow (Hensold and Giulietti 1991), the anatomical characteristics of the vegetative organs promote better hydrodynamic, allowing movements and decreasing water resistance. It can be emphasized that the peculiar anatomical characteristics of the leaves of $R$. capillaceus is related to the fact that they are submerged. As shown in other aquatic and amphibious species, the submerged-type leaves are generally thin, without stomata, and with a large surface area, characteristics that make them better suited to absorb water and nutrients and harvest the lower light levels underwater (Sculthorpe 1967). In R. capillaceus, however, since the leaves are filiform, they do not present a large surface area, but the chloroplasts occurs only in the epidermis, favoring the light absorption for the photosynthesis. In addition, the short, thin-walled epidermal cells with a thin cuticle may reduce the resistance against carbon dioxide and oxygen uptake, which probably occurs by diffusion, since the stomata are absent. It has already been demonstrated that when the leaves of terrestrial plants (or aerial leaves of amphibious plants) become submersed, the gas exchange occurs predominantly via diffusion across the cuticle (Frost-Christensen et al. 2003; Mommer and Visser 2005; Frost-Christensen and Floto 2007). Submerged species with thin or finely dissected leaves have a higher photosynthetic rate (Sand-Jensen et al. 1992), probably because of this low diffusional resistance to uptake of nutrients and gases (Frost-Christensen et al. 2003; FrostChristensen and Floto 2007).

The phylogenetic analyses of Eriocaulaceae used molecular data of $R$. capillaceus and have not found strong support 
for the phylogenetic position of the genus (Andrade et al. 2010; Giulietti et al. 2012). The analyses based on nuclear (ITS) and plastid DNA (trn $\mathrm{H}-p s b \mathrm{~A}$ and $t r n \mathrm{~L}-\mathrm{F})$ indicated that Rondonanthus is sister to the rest of Paepalanthoideae in the combined plastid analysis, but in the combined plastid + nuclear analysis it appears in a more derived position within the subfamily, sister to the clade formed by Lachnocaulon, Tonina, Paepalanthus and Actinocephalus (Andrade et al. 2010). In a more recent analysis that presented new data for the ITS and trnL-F regions, Rondonanthus also appears nested in Paepalanthoideae as sister group to Leiothrix in both ITS and combined analysis (Giulietti et al. 2012). Considering the results herein obtained, it is important to highlight that $R$. capillaceus should not be used as a model for the genus characterization. In addition, the anatomical similarity between Rondonanthus and Leiothrix can be resulted from adaptive convergence, since several species of Leiothrix are aquatic. The inclusion of more species of Rondonanthus in further analyses is necessary to better clarify the phylogenetic position of the genus.

Acknowledgments We thank the FAPESP—Fundação de Amparo à Pesquisa do Estado de São Paulo (Process numbers 2013/00383-7, 2011/11536-3) and the CNPq-Conselho Nacional de Desenvolvimento Científico e Tecnológico (Process number 168277/2014-0) for financial support. We also thank Dr Paulo Takeo Sano for assistance with the plant material.

\section{References}

Alves PGM, Scatena VL, Trovó M (2013) Anatomy of scapes, bracts, and leaves of Paepalanthus sect. Diphyomene (Eriocaulaceae, Poales) and its taxonomic implications. Brittonia 65:262-272

Andrade MJG, Giulietti AM, Rapini A, Queiroz LP, Conceição AS, Almeida PRM, Van Den Berg C (2010) A comprehensive phylogenetic analysis of Eriocaulaceae: evidence from nuclear (ITS) and plastid ( $p s b \mathrm{~A}-\operatorname{tr} n \mathrm{H}$ and $\operatorname{trn} \mathrm{L}-\mathrm{F}$ ) DNA sequences. Taxon 59:379-388

Andrade MJG, Giulietti AM, Harley RM, Van Den Berg C (2011) Blastocaulon (Eriocaulaceae), a synonym of Paepalanthus: morphological and molecular evidence. Taxon 60:178-184

Castro NM, Menezes NL (1995) Aspectos da anatomia foliar de algumas espécies de Paepalanthus Kunth, Eriocaulaceae, da Serra do Cipó (Minas Gerais). Acta Bot Bras 9:213-229

Coan AI, Scatena VL, Giulietti AM (2002) Anatomia de algumas espécies aquáticas de Eriocaulaceae brasileiras. Acta Bot Bras 16:371-384

Diggle PK, DeMason DA (1983) The relationship between the primary thickening meristem and the secondary thickening meristem in Yucca whipplei Torr. I. histology of the mature vegetative stem. Amer J Bot 70:1195-1204

Frost-Christensen H, Floto $\mathrm{F}$ (2007) Resistance to $\mathrm{CO}_{2}$ diffusion in cuticular membranes of amphibious plants and the implication for $\mathrm{CO}_{2}$ acquisition. Pl Cell Environ 30:12-18

Frost-Christensen H, Bolt Jorgensen L, Floto F (2003) Species specificity of resistance to oxygen diffusion in thin cuticular membranes from amphibious plants. Pl Cell Environ 26:561-569

Giulietti AM, Scatena VL, Sano PT, Parra LR, Queiroz LP, Harley RM, Menezes NL, Ysepon AMB, Salatino A, Salatino ML,
Vilegas W, Santos LC, Ricci CV, Bonfim MCP, Miranda EB (2000) Multidisciplinary studies on Neotropical Eriocaulaceae. In: Wilson KL, Morrison DA (eds) Monocots: Systematics and Evolution. CSIRO Publishing, Melbourne, pp 580-589

Giulietti AM, Andrade MJG, Scatena VL, Trovó M, Coan AI, Sano PT, Santos FAR, Borges RLB, Van Den Berg C (2012) Molecular phylogeny, morphology and their implications for the taxonomy of Eriocaulaceae. Rodriguésia 63:1-19

Hensold NC, Giulietti AM (1991) Revision and redefinition of the genus Rondonanthus Herzog (Eriocaulaceae). Ann Mo Bot Gard 78:441-459

Herzog T (1931) Neue und weniger bekannte Eriocaulonaceae aus Nordbrasilien und dem angrenzenden Venezuela. Feddes Repert 29:202-213

Johansen DA (1940) Plant Microtechnique. Mc- Graw-Hill Book Company, New York

Keates SE, Tarlyn NM, Loewus FA, Franceschi VR (2000) L-ascorbic acid and L-galactose are sources of oxalic acid and calcium oxalate in Pistia stratiotes. Phytochemistry 53:433-440

Malmanche LA 1919 Contribution à l'étude anatomique des Eriocaulonacées et des familles voisines: Restiacées, Centrolépidacées, Xyridacées, Philydracées, Mayacacées Thesis, St. Cloud, Paris

Menezes NL, Silva DC, Arruda RCO, Melo-de-Pinna GF, Cardoso VA, Castro NM, Scatena VL, Scremin-Dias E (2005) Meristematic activity of the endodermis and the pericycle in the primary thickening in monocotyledons: considerations on the "PTM". An Acad Bras Cienc 77:259-274

Molano-Flores B (2001) Herbivory and calcium concentrations affect calcium oxalate crystal formation in leaves of Sida (Malvaceae). Ann Bot 88:387-391

Mommer L, Visser EJW (2005) Underwater photosynthesis in flooded terrestrial plants: a matter of leaf plasticity. Ann Bot 96:581-589

Monteiro WR, Giulietti AM, Mazzoni SC, Castro MM (1979) Hairs on reproductive organs of some Eriocaulaceae and their taxonomic significance. Bol Bot Univ São Paulo 7:43-59

Monteiro WR, Giulietti AM, Castro MM (1984) Aspects of leaf structure of some species of Eriocaulon L. (Eriocaulaceae) from Serra do Cipó (Minas Gerais, Brazil). Rev Bras Bot 7:137-147

Monteiro WR, Castro MM, Giulietti AM (1985) Aspects of leaf structure of some species of Leiothrix Ruhl. (Eriocaulaceae) from the Serra do Cipó (Minas Gerais, Brazil). Rev Bras Bot 8:109-125

Oriani A, Scatena VL, Sano PT (2005) Anatomia das folhas, brácteas e escapos de Actinocephalus (Koern.) Sano (Eriocaulaceae). Rev Bras Bot 28:229-240

Oriani A, Scatena VL, Sano PT (2008) Morphological architecture of Actinocephalus (Koern.) Sano (Eriocaulaceae). Flora 203: 341-349

Parra LR, Giulietti AM, Andrade MJG, Van Der Berg C (2010) Reestablishment and a new circumscription of Comanthera (Eriocaulaceae). Taxon 59:1135-1146

Poulsen VA (1888) Anatomiske studien over Eriocaulaceerne. Vidensk Meddr Dansk Naturhistorisk Foren 4:221-386

Roeser KR (1972) Die Nadel der Schwarzkiefer - Massenprodukt und Kunstwerk der Natur. Mikrokosmos 61:33-36

Ruhland W (1903) Eriocaulaceae. In: Engler A (ed) Das Pflanzenreich IV. Engelmann, Leipzig, pp 1-294

Sand-Jensen K, Pedersen MF, Nielsen SL (1992) Photosynthetic use of inorganic carbon among primary and secondary water plants in streams. Freshw Biol 27:283-293

Sano PT (2004) Actinocephalus (Koern.) Sano (Paepalanthus sect. Actinocephalus), a new genus of Eriocaulaceae, and other taxonomic and nomenclatural changes involving Paepalanthus Mart. Taxon 53:99-107 
Scatena VL (1990) Morfoanatomia de espécies de Syngonanthus Ruhl. (Eriocaulaceae) dos campos rupestres do Brasil. PhD Thesis, Universidade de São Paulo, Brazil

Scatena VL, Menezes NL (1995) Aspectos morfológicos e anatômicos do caule em espécies de Syngonanthus Ruhl. Eriocaulaceae. Bol Bot Univ São Paulo 14:91-107

Scatena VL, Menezes NL (1996a) Anatomia de escapos e folhas de Syngonanthus Ruhl. (Eriocaulaceae) de Campos Rupestres. Rev Bras Biol 56:317-332

Scatena VL, Menezes NL (1996b) Anatomia de raízes de Syngonanthus Ruhl. (Eriocaulaceae). Rev Bras Biol 56:333-343

Scatena VL, Moraes ARS (1996) Anatomia de raízes, folhas e escapos de espécies de Paepalanthus subgênero Platycaulon (Eriocaulaceae). Arq Biol Tecnol 39:1021-1035

Scatena VL, Rocha CLM (1995) Anatomia dos órgãos vegetativos e do escapo floral de Leiothrix crassifolia (Bong.) Ruhl., Eriocaulaceae, da Serra do Cipó-MG. Acta Bot Bras 9:195-211

Scatena VL, Rosa MM (2001) Morphology and anatomy of the vegetative organs and scapes from Aphorocaulon (Paepalanthus, Eriocaulaceae). Braz Arch Biol Technol 44:49-58

Scatena VL, Scremin-Dias E (2012) Parênquima, colênquima e esclerênquima. In: Appezzato-da-Glória B, Carmello-Guerreiro SM (eds) Anatomia vegetal, 3rd edn. Editora UFV, Viçosa, pp 109-128

Scatena VL, Cardoso VA, Giulietti AM (1999a) Morfoanatomia de espécies de Blastocaulon Ruhland (Eriocaulaceae). Acta Bot Bras 13:29-41
Scatena VL, Giulietti AM, Cardoso VA (1999b) Anatomia de raízes, escapos e folhas de espécies de Eriocaulon L. (Eriocaulaceae). Bol Bot Univ São Paulo 18:11-20

Scatena VL, Vich DV, Parra LR (2004) Anatomia de escapos, folhas e brácteas de Syngonanthus sect. Eulepis (Bong ex. Koern.) Ruhland (Eriocaulaceae). Acta Bot Bras 18:825-837

Scatena VL, Giulietti AM, Borba EL, Van Den Berg C (2005a) Anatomy of Brazilian Eriocaulaceae: correlation with taxonomy and habitat using multivariate analyses. Plant Syst Evol 253:1-22

Scatena VL, Oriani A, Sano PT (2005b) Anatomia de raízes de Actinocephalus (Koern.) Sano (Eriocaulaceae). Acta Bot Bras 19:835-841

Sculthorpe CD (1967) The Biology of Aquatic Vascular Plants. Edward Arnold Ltda, London

Smith KA, Russel RS (1966) Occurrence of ethylene, and its significance, in anaerobic soil. Nature 222:769-771

Stützel T (1988) Untersuchungen zur Wurzelanatomie der Eriocaulaceen. Flora 180:223-239

Stützel T (1998) Eriocaulaceae. In: Kubitzki K (ed) The families and genera of vascular plants - IV Monocotyledons. Springer Verlag, Berlin, pp 197-207

Terashima I, Miyazawa S-I, Hanba YT (2001) Why are sun leaves thicker than shade leaves? - consideration based on analyses of $\mathrm{CO}_{2}$ diffusion in the leaf. J Plant Res 114:93-105

Tomlinson PB (1969) Eriocaulaceae. In: Metcalfe CR (ed) Anatomy of the monocotyledons III: Commelinales - Zingiberales. Clarendon Press, Oxford, pp 146-192 